\title{
I $\mathbf{E}$
}

\section{ЕКОНОМІКА ТА ІННОВАЦІЙНИЙ РОЗВИТОК НАЦІОНАЛЬНОГО ГОСПОДАРСТВА}

UDC 330.34

DOI: 10.37332/2309-1533.2020.1-2.1

JEL Classification: D 83, 031

Honcharenko I.V.,

dr.sc.(econ.), professor, professor at the department of public management, administration and international economics, Mykolaiv National Agrarian University,

Bohoslavsкa A.V., dr.sc.(econ.), assoc. prof., associate professor at the department of international economic relations and economics, Mykolaiv National University named after V.O. Sukhomlynskyi, Moroz T.O., cand.sc.(econ.), associate professor at the department of information systems and technologies, Mykolaiv National Agrarian University,

\section{COMPETITIVE ADVANTAGES OF THE IMPLEMENTATION OF THE ACADEMIC VIRTUAL MOBILITY PROJECTS}

Гончаренко I.B., д-р екон. наук, професор, професор кафедри публічного управління та адміністрування і міжнародної економіки, Миколаївський національний аграрний університет, Богославська А.В., д-р екон. наук, доцент, доцент кафедри міжнародних економічних відносин та економіки, Миколаївський національний університет ім. В.О. Сухомлинського, Мороз T.O., канд. екон. наук, доцент кафедри інформаційних систем і технологій, Миколаївський національний аграрний університет

\section{КОНКУРЕНТНІ ПЕРЕВАГИ ЗАПРОВАДЖЕННЯ ПРОЕКТІВ ВІРТУАЛЬНОÏ АКАДЕМІЧНОЇ МОБІЛЬНОСТІ}

Formulation of the problem. Post-industrial economic development and globalization have led to a change in the value orientations of education, which is no longer just about a national seclusion and selfsufficiency, but rather is about a strategy of internationalization. The spread of internationalization is facilitated by student exchange. The global mobility of students is increasing, and the factors contributing to it have not lost their weight for decades. Restrictions on access to higher education and lack of potential for satisfying personal and professional goals are driving the rise of the number of students from all over the world who choose to study abroad. The OECD estimates that more than 5 million students crossed the border in 2018, showing an increase from 2.1 million who went abroad in 2001 [7]. Institutions of various levels are actively pursuing initiatives that compete for global talent predicting a further increase in the number of people who want to study abroad.

This article shows the competitive advantages of virtual academic mobility projects and solves the problem of the availability of academic mobility for rising of the students' competence.

Analysis of recent research and publications. According to Choudaha Rahul and De Wit Hans, the aspiration for studying abroad is driven by a complex interplay of many variables. However, one of the key 
determinants of conversion of aspirations into reality is the availability of financial resources to study abroad. As a result, the biggest part of globally mobile students come from high- and upper middle-income countries, who respectively account for $27 \%$ and $40 \%$ of total outwardly mobile students. Lower middle-income and low-income countries made up 33\% of outward mobility in 2017 [2]. A confluence of trends indicates that studying abroad is going to become more expensive. Given the changing landscape of international student mobility, sustainable growth will require proactive actions by universities to deliver value for money. Institutions will therefore need to complement traditional student mobility with innovations in program offerings and delivery methods, including online learning.

Researchers should find an opportunity for universities to shift from a focus on increasing quantitative indicators to enhancing the quality of academic mobility.

Setting objectives. The purpose of the research is to show the competitive advantages of virtual academic mobility projects and to solve the problem of the availability of academic mobility for rising of the students' competence.

Presentation of the main research material. In the European Union, Erasmus has become a regional leader in supporting the academic mobility of students. For more than 30 years, it attracts students who have a desire to gain international experience and are interested in improving their career prospects. The program was created by the European Commission in 1987 to promote student and cultural exchange between European countries. It enables students of higher education institutions from European Union countries and a group of countries beyond its borders, to take short-term study abroad, often, it lasts one semester. Since the inception of the program, 9 million people have studied or worked abroad with the support of Erasmus. In recent years, Erasmus has expanded its training, volunteering, and Erasmus Mundus and Erasmus programs. For the years 2014-2020, a budget of $€ 14.7$ billion is envisaged, enabling more than 4 million participants to study, train, gain experience and volunteer abroad [4]. Along with the processes of internationalization of education, there are trends that indicate increasing problems with obtaining visas, the presence of an unwanted atmosphere for foreigners in host countries, increasing of the cost of education, devaluation of the currencies of middle and lower income countries and the depletion of the scholarships. There is a high probability, that students from both low-income and low-middle-income countries will find it harder to study abroad. Some prospective Erasmus students have a low level of foreign language skills, especially English [1], which is the predominant language of scientific communication and research. In this context, a call for an approach with a stronger emphasis on "internationalization at home" by the Rector of the University of Amsterdam, as well as Jones and De Wit, can be seen as an opportunity for universities to shift from a focus on increasing quantitative indicators to enhancing the quality of academic mobility [3; 6; 9].

The Studyportals' report identifies a set of transformational changes or megatrends that are expected to push higher education institutions in high-income countries to open the way to more relevant, accessible and flexible academic programs that offer more career-related experience and economic benefits [5]. Thus, it's very important to supplemented traditional student mobility with innovation in programs and teaching methods, including virtual mobility, which as a form of university interaction has emerged at the intersection of e-learning and international collaboration and allows students to participate in courses and programs of other institutions.

Van der Wende M. emphasizes that virtual mobility programs and virtual universities are now the basis for students' virtual mobility, based on the use of new information computer technologies in higher education, primarily Internet and mobile learning environments. E-learning promotes global access to higher education, contributing to pedagogical innovation and reducing the cost of learning. Online education, which is the most modern and dynamic form of educational service organization, is also a form of supranational education. Its development is facilitated by virtual courses, universities and academies, virtual libraries, electronic resources. One of the latest achievements is the launch of an online graduate school in Italy, which educates several dozen countries. Nowadays, virtual universities and combined education are in serious competition with traditional universities and full-time study. Information and communication technologies have caused the explosion of international information mobility. New technologies enable more students to have international contacts and access to information. Distance and time is no longer an obstacle [10].

Virtual mobility reduces the cost and time spent on organizing collaboration between students and teachers from different countries and regions, regardless of place of residence. It is especially relevant for students who cannot participate in traditional exchange programs for various reasons. Virtual mobility programs can also be a good opportunity to acquire the necessary speech competence - the ability to listen and understand, speak, read and write, that is, to be free to possess all types of speech activity for physical mobility, because quite often it requires the possession of one or several foreign languages, the basic conditions for students' participation in programs of study at foreign universities and effective participation in international educational and scientific projects are proficiency in English or in language of the partner institution at a level not lower than B2 in accordance with the pan-European Foreign Languages (CEFR) [7].

Communication between participants requires the ability to adequately and appropriately, practically use the language chosen to communicate in specific situations (express their thoughts, desires, intentions, considerations, etc.), use both linguistic and non-verbal means and intonation tools of expressing speech through the development of four types of speech activity: listening, reading, speaking, writing. This is an effective factor in motivating students to further improve of their foreign language skills. Language learning is 
a joining to the richness of another culture, another way of thinking, a different perspective on the world, or at least a deeper understanding of how other cultures perceive the world.

Students need to develop the following skills: communication in different situations, discussion of problems and ways to overcome them; collaboration in a project team. The process of forming communicative abilities includes intrinsic motivation, ability to organize speech, orientation in a communication situation, remember what was said by the interlocutor.

Our experience in participating in the Erasmus + MILETUS Students Mobility Capacity Building in Education in Ukraine and Serbia project, which seeks to build capacity in virtual, real and mixed mobility in higher education institutions in Serbia and Ukraine, confirms the effectiveness of student engagement in problem solving and decision making, improving their communicative skills and professional training. Compared to online course platforms such as MOOC (Massive Open Online Courses) and other online programs, MILETUS virtual mobility programs provide project based learning (Problem Based Learning) where students can gain knowledge and skills while working on a collaborative project [8].

The participants represented Germany, Denmark, Italia, Serbia and Ukraine. They conducted meeting and creating concept of virtual mobility for the project. Univ.- Prof. Dr. Thorsten Blecker Hamburg University of Technology Institute of Business Logistics and General Management showed short country overview of Serbia and Ukraine in aspects of science, technological development and innovation activity and his vision of perspectives of innovation, he stressed on open innovation processes which were characterized, in contrast to traditional closed innovation processes, by the fact that actors disclose their innovations ("free revealing") without expecting an immediate return therefore.

He gives interesting examples grassroots innovation as:

- Community-led solutions for sustainability (e.g.: promising new ideas and practices, but often struggle to scale up and spread beyond small niches);

- Networks of activists and organizations generating novel bottom up solutions for sustainable development.

Dr. Thorsten Blecker expanded us technology transfer as the movement of technological and technology-related organizational know-how among partners (individuals, institutions, and enterprises) in order to enhance at least one partner's competitive position. Workshops were targeted on the new ideas generating in the sphere of students' academic mobility activation, more attention was given to the question of providing virtual mobility.

Dr. Larsen from Aalborg University, Denmark introduced the philosophy of Problem based learning for us. The PBL-model assumes that students learn best when applying theory and research based knowledge in their work with an authentic problem. At the same time, the model supports students in the development of their communication and cooperation competences and in acquiring the skills required when taking an analytical and result-oriented approach.

The AAU model includes project work based on authentic problems, self-governed group work and collaboration. The AAU model provides students with tools for independent acquisition of knowledge, skills and competences at an advanced academic level. During their studies, many students will also have the opportunity to cooperate with external partners on the solution of scientific problems.

At the beginning stage of the virtual mobility, students were offered a video course on research methodology, after which multiple-choice test questions and an internationalization course were conducted.

In cooperation with the supervisor, students of our project team studying biotechnology, management and philology selected the topic of research relevant for each team member, organized internal communication, assigned roles and responsibilities for all team members, defined goals and methods of the project, formulated it plan and finally prepared the project documentation.

The analysis of the results shows that participation in the project increased the students' motivation to learn a foreign language, since in this case language learning becomes a tool of creating the end product of the activity. Communication using Internet communication technology that occurred between two or more participants at one time interval (for example, with the help of messengers, chat, video and audio conferences is a little unprepared, spontaneous and emotional) and brings the student closer to use communicative skills in real-life (and virtual channels) communication conditions. Continuing learning, selfimprovement, creative search: Through electronic communication, the student becomes a participant in the global process of rapid updating and exchange of information, which inevitably arouses his interest and motivates him to practice foreign language communication.

An important factor of achieving positive results on the Erasmus + MILETUS project is to create favourable conditions for the student to feel successful and intelligent. Students collectively gain new knowledge by organizing activities from one-to-two individual interactions to broad team collaboration. The teacher thus performs the functions of assistant in the work, consultant, organizer, becomes one of the sources of information. At the same time, the student and the teacher act as equal subjects during the work.

Conclusions from the conducted research. The value of implementing virtual mobility projects, as demonstrated by the MILETUS experience, is also in facilitating the internationalization of the educational process by preparing students to participate effectively in international educational and research activities as students gain experience working in international, inter-institutional and interdisciplinary teams together with colleagues from other countries and colleagues universities, and also address the problem in terms of different subject areas with a common understanding of lecture topics. The success of its implementation depends on the quality of training and methodological support; use of relevant forms, methods and modes of 
work, which will contribute to the formation of a generation of young people, able to make personal spiritual outlook, acquire the necessary knowledge, skills and competences to integrate into the world community.

\section{Literature}

1. Altbach Philip G., De Wit Hans The challenge to higher education internationalization. URL: https://www.universityworldnews.com/post.php?story=20180220091648602en (дата звернення: 04.02.2020).

2. Choudaha Rahul, De Wit Hans. Finding a sustainable future for student mobility. URL: https://www.universityworldnews.com/post.php?story=20190205110138464 (дата звернення: 02.02.2020).

3. Common European Framework of Reference for Languages: Learning, teaching, assessment (CEFR). URL: https://www.coe.int/en/web/portfolio/the-common-european-framework-of-reference-forlanguages-learning-teaching-assessment (дата звернення: 01.02.2020).

4. Erasmus+ is the EU's programme to support education, training, youth and sport in Europe. URL: https://ec.europa.eu/info/education/set-projects-education-and-training/erasmus-funding-programme_en (дата звернення: 02.02.2020).

5. International Student Interest Dashboard, URL: https://www.studyportals.com (дата звернення: 05.02.2020).

6. Internationalization at home: A position paper / Crowther P., Joris M., Otten M., Nilsson B., Teekens H. \& Wächter B. Amsterdam : EAIE, 2001. URL: http://citeseerx.ist.psu.edu/viewdoc/download? doi=10.1.1.123.3826\&rep=rep1\&type=pdf (дата звернення: 01.02.2020).

7. Project Atlas 2018: Infographics. URL: https://www.iie.org/en/Research-and-Insights/ProjectAtlas/Explore-Data/Current-Infographics (дата звернення: 04.02.2020).

8. Project details. URL: https://miletus.mnau.edu.ua (дата звернення: 02.02.2020).

9. Souto-Otero M., Huisman J., Beerkens M., De Wit H. Barriers to international student mobility: Evidence from the Erasmus program. URL: https://www.researchgate.net/publication/258134759_Barriers_to _International_Student_Mobility_Evidence_From_the_Erasmus_Program (дата звернення: 04.02.2020).

10. Wende M. van der Internationalization of Higher Education. International Encyclopedia of Education. Academic Press, 2010. P. 540-545.

\section{References}

1. Altbach, Philip G. and De Wit, Hans "The challenge to higher education internationalization", available at: https://www.universityworldnews.com/post.php?story=20180220091648602en (access date February 04, 2020).

2. Choudaha Rahul, De Wit Hans "Finding a sustainable future for student mobility", available at: https://www.universityworldnews.com/post.php?story=20190205110138464 (access date February 02, 2020).

3. Common European Framework of Reference for Languages: Learning, teaching, assessment (CEFR), available at: https://www.coe.int/en/web/portfolio/the-common-european-framework-of-referencefor-languages-learning-teaching-assessment (access date February 01, 2020).

4. Erasmus+ is the EU's programme to support education, training, youth and sport in Europe, available at: https://ec.europa.eu/info/education/set-projects-education-and-training/erasmus-fundingprogramme_en (access date February 02, 2020).

5. International Student Interest Dashboard, available at: https://www.studyportals.com (access date February 05, 2020).

6. Crowther, P., Joris, M., Otten, M. et al. (2001), Internationalization at home: A position paper, EAIE, Amsterdam, Netherlands, available at: http://citeseerx.ist.psu.edu/viewdoc/download? doi=10.1.1.123.3826\&rep=rep1\&type=pdf (access date February 01, 2020).

7. Project Atlas 2018: Infographics, available at: https://www.iie.org/en/Research-and-Insights/ProjectAtlas/Explore-Data/Current-Infographics (access date February 04, 2020).

8. Project details, available at: https://miletus.mnau.edu.ua (access date February 02, 2020).

9. Souto-Otero, M., Huisman, J., Beerkens, M. and De Wit, H. "Barriers to international student mobility: Evidence from the Erasmus program", available at: www.researchgate.net/publication/ 258134759_Barriers_to_International_Student_Mobility_Evidence_From_the_Erasmus_Program (access date February 04, 2020).

10. Wende M. van der (2010), "Internationalization of Higher Education", International Encyclopedia of Education, Academic Press, Oxford, United Kingdom, pp. 540-545.

Стаття надійшла до редакції 14.02.2020 p. 